Research Article

\title{
Comparative study of amlodipine versus ramipril and their effects on markers of renal disease in type 2 diabetes mellitus
}

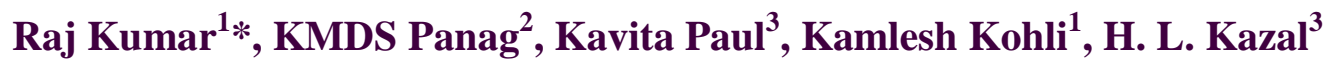

${ }^{1}$ Department of Pharmacology, GGS Medical College and Hospital (Baba Farid University of Health and Sciences), Faridkot, Punjab, India, ${ }^{2}$ Department of Biochemistry, GGS Medical College and Hospital (Baba Farid University of Health and Sciences), Faridkot, Punjab, India, ${ }^{3}$ Department of Medicine, Punjab Institute of Medical Sciences, Jalandhar, Punjab, India

Received: 24 January 2016 Accepted: 02 March 2016

*Correspondence to: Dr. Raj Kumar, Email: anurajkumar76@ gmail.com

Copyright: (c) the author(s), publisher and licensee Medip Academy. This is an openaccess article distributed under the terms of the Creative Commons Attribution NonCommercial License, which permits unrestricted noncommercial use, distribution, and reproduction in any medium, provided the original work is properly cited.

\begin{abstract}
Background: Diabetes mellitus is a chronic metabolic condition and patients require long treatment for it. The aim of the study was to evaluate the effects of amlodipine and ramipril on the blood pressure and markers of renal disease (viz. serum creatinine, albuminuria and eGFR) in type 2 diabetes mellitus.

Methods: This was a randomized, open labelled, parallel study conducted to assess the effect of Amlodipine (2.5-10 mg) and Ramipril (2.5-10 mg) daily for 24 weeks in T2DM patients $(n=103)$. Patients were recruited from department of Medicine OPD/Ward in the GGS Hospital and Medical College, Faridkot. Subjects in the age group of 30- 80 years who had T2DM with or without hypertension were enrolled and randomly divided into two groups viz. Group A $(\mathrm{n}=51$, amlodipine 2.5 to $10 \mathrm{mg} /$ day) and Group $\mathrm{B}(\mathrm{n}=52$, ramipril 2.5 to $10 \mathrm{mg} /$ day). Patients were evaluated at day 0 and then at 12 and 24 weeks for Blood pressure, S. Creatinine, albuminuria, eGFR and other routine investigations.

Results: At 24 weeks SBP, DBP and MAP values were decreased significantly in both the groups ( $\mathrm{p}<0.0001$, each). At 24 weeks, there were increased in the levels of albumin in urine $(59.87 \%, \mathrm{p}<0.0001)$ and serum creatinine $(24.93 \%$, $\mathrm{p}<0.001)$ in the Amlodipine group while fall in these levels were observed $(26.75 \%, p<0.0001$ and $5.95 \%, p>0.05)$ in Ramipril group. eGFR was decreased $(9.73 \%, \mathrm{p}<0.01)$ in Amlodipine group while increased in Ramipril group $(10.29 \%, \mathrm{p}<0.01 \%)$.

Conclusions: Both amlodipine and ramipril are equally efficacious in improving SBP, DBP and MAP in T2DM patients. Whereas, ramipril is also improves the markers/predictors of renal disease (viz. serum creatinine, albumin level in urine and eGFR) in T2DM patients, furthermore, it is having renoprotective action in an addition to lowering raised blood pressure which is useful to treat diabetic nephropathy cases.
\end{abstract}

Keywords: T2DM, Predicators/Markers of renal disease, ACEI (Angiotensin Converting Enzyme Inhibitor), Blood Pressure, Calcium channel blocker (CCBs), Renoprotective, eGFR, Microalbuminuria

\section{INTRODUCTION}

Diabetes mellitus is a chronic metabolic condition and patients require long treatment for it. ${ }^{1}$ The prevalence of this disease across the world was estimated to be $2.8 \%$ in 2000 and $4.4 \%$ in 2030 . The number of people affected with diabetes is projected to increase from 172 million in 2000 to 366 million in 2030 and 471 million in 2035 (and this projected rise will be by $55 \%) .^{2-4}$ It has been seen that diabetic patients also have other co-morbid conditions/complications (viz. Hypertension, CAD, dyslipidemia, neuropathy, nephropathy etc.). ${ }^{1-3}$ It is important to treat the diabetic patients wisely to keep in mind all these co-morbid conditions too. In diabetes, the commonest co-morbid conditions are type 2 diabetes mellitus (T2DM) with hypertension, T2DM with nephropathy, T2DM with CAD, T2DM with neuropathy, etc. ${ }^{1,4-6}$ While, T2DM with hypertension is the major cause of diabetic nephropathy which is one of the serious type of complication that lead to end stage renal disease 
(ESRD) if not detected or managed at an early satge. ${ }^{1,4-6}$ Studies have revealed that albumin level in urine and eGFR are the predictors of renal function. Both are sensitive markers and directly associated with the functioning of kidney. ${ }^{6,7}$ If, we can identify risk factors like hyperglycaemia, raised blood pressure and markers of renal disease viz. serum creatinine, albumin in urine and eGFR ( estimated Glomerular Filtration Rate) in the patients at early stage, then we would save the life of many patients from such serious life threatening complication (ESRD or Chronic kidney Disease) by taking appropriate steps. ${ }^{1,4-7}$ Studies have shown that antihypertensive agents e.g. CCBs (Calcium Channel Blockers), ACEIs (Angiotensin Converting Enzyme Inhibitor), ARBs (Angiotensin Receptor Blockers), Beta blockers, Alpha Blockers, etc.) reduce the incidence of serious life threatening complications like Cardiovascular Diseases (CVDs) and Nephropathy., ${ }^{4,5-9}$ Both CCBs and ACEI are commonly prescribed for the management of hypertension in diabetic patients. ${ }^{5,7,8,10}$ Amongst CCBs, Amlodipine is commonly prescribed for management of hypertension in diabetic patients as it shows various favourable effects on blood pressure, heart rate and atherosclerotic process and thus, reduces the CVDs events. Therefore, it is one of the agents having lesser side effects and well tolerated by the patients. ${ }^{5,7-9}$

ACE inhibitors (Ramipril, Enalapril, lisinopril, etc.) are agents that inhibit conversion of angiotensin $I$ to angiotensin II (which is potent vasoconstrictor) has antihypertensive, antiatherosclerotic effects and also improve the intraglomerular pressure in the kidney (thus, improved intrarenal hemodynamics, with decreased glomerular efferent arteriolar resistance and a resulting reduction of intraglomerular capillary pressure) hence prevents the renal complication. ${ }^{1,5,7,9}$

There is paucity of data available about the efficacy and safety of these antihypertensive agents' in the Indian patients with respect to their role in the prevention of renal complication. Therefore, in this study we are going to evaluate the role of these agents in the markers of renal disease that directly or indirectly shows status of renal function. This is a randomized controlled trial of Amlodipine (CCBs) and Ramipril (ACEI) done in T2DM patients in Northern India.

Primary End Point in this study is to evaluate the effects of study drugs on the Blood Pressures and Secondary End Points to evaluate effects on the markers of renal disease (viz. serum creatinine, albuminuria and eGFR) and safety of these agents in type 2 diabetes mellitus.

\section{METHODS}

This was a randomized, open-labelled, parallel, intention to treat study, conducted to assess the effects of Amlodipine (2.5-10 mg/day) and Ramipril (2.5-10 $\mathrm{mg} /$ day) in patients of type 2 diabetes mellitus with or without hypertension, for 24 weeks. 103 patients $(n=51$ in
Group $\mathrm{A}$ and $\mathrm{n}=52$ in Group B) of type 2 diabetes patients were selected visiting the OPD and Ward of Department of Medicine, GGS Medical College and Hospital, Faridkot. The Institutional Ethical Committee had approved the protocol of this study and all subjects were enrolled into the study after taking their written informed consent from them. Both the study drugs have been allocated among the patients randomly by using random number table. Patients were evaluated at day 0 and then at 12 weeks and 24 weeks for clinical examination and other parameters. While, blood pressure was recorded on every visit (at 2, 4, 6, 12, 20 and 24 weeks) and titration of the study drugs were done according to blood pressure in the patients. Blood glucose levels are also considered to take care of the patients at each visit and doses of oral hypoglycaemic agents are titrated too. Estimated Glomerular Filtration rate (eGFR) was estimated with the MDRD (Modification of diet in Renal Disease formula) equation. ${ }^{5}$ Albumin in urine level was detected by the spot method (Spot microalbuminuria). ${ }^{11}$

\section{Inclusion and exclusion criteria}

Patients of either sex with age 30-80 years diabetic patients was diagnosed according to IDF (with fasting blood sugar $\geq 126 \mathrm{mg} / \mathrm{dl}$ or random blood sugar $\geq 200$ $\mathrm{mg} / \mathrm{dl}$ or oral glucose tolerance test value of $\geq 200 \mathrm{mg} / \mathrm{dl}$ in the 2- hour sample) or patient already taking oral hypoglycaemic agents (OHA). ${ }^{4}$ While patients with age $<30$ years, those having diabetes with severe cardiovascular disorders, those taking steroid or hormonal therapy, hepatic, renal disorders (s. creatinine $>2.5 \mathrm{mg} / \mathrm{dl}$ or renal artery stenosis) and thyroid disorders, pregnant and lactating women, contraindications to calcium blockers or ACE inhibitors, patients on nonsteroidal anti-inflammatory agents (except low dose aspirin) and patients who refused written informed consent and not follow the protocol /instructions were excluded from the study.

\section{Sample size and statistical analysis}

A sample size of 50 (included dropout) for each arm was calculated to have $80 \%$ power and $\alpha=0.05$ to detect a $30 \%$ difference in blood pressure after therapy with the study drugs. Data were expressed as mean and standard deviation (SD). Students't test applied between the groups and post-hoc ANOVA within the group (if $p<0.05$ within the group). Fischer exact test was also applied to non-parametric values. Value of $\mathrm{p}<0.05$ is considered to be statistical significant.

\section{RESULTS}

Baseline characteristics (Table 1) and baseline levels of different parameters (Table 2) of the Group A and Group $\mathrm{B}$ were compared at the start of therapy. The difference in both the groups was statistically insignificant $(\mathrm{p}>0.05)$ at baseline therapy of amlodipine and ramipril in group. 
Table 1: Baseline characteristics of the population.

\begin{tabular}{|llll|}
\hline Parameters & $\begin{array}{l}\text { Amlodipine } \\
\mathbf{n = 5 1}\end{array}$ & $\begin{array}{l}\text { Ramipril } \\
\mathbf{n = 5 2}\end{array}$ & $\begin{array}{l}\text { p- } \\
\text { value* }\end{array}$ \\
\hline Age & 52.196 & 55.57 & $>0.05$ \\
\hline $\begin{array}{l}\text { Sex } \\
\text { Male }\end{array}$ & 35 & 30 & \\
female & 16 & 22 & - \\
\hline Alcoholic & 20 & 21 & $>0.05$ \\
\hline Smoker & 02 & 02 & $>0.05$ \\
\hline Vegetarian & 32 & 28 & $>0.05$ \\
\hline T2DM with HT & 41 & 48 & $>0.05$ \\
\hline $\begin{array}{l}\text { Family history } \\
\text { of diabetes } \\
\text { mellitus }\end{array}$ & 26 & 25 & $>0.05$ \\
\hline $\begin{array}{l}\text { Family history } \\
\text { of hypertension }\end{array}$ & 11 & 10 & $>0.05$ \\
\hline $\begin{array}{l}* \text { Students't test unpaired applied } \\
\text { Value }\end{array}$ & & \\
\hline
\end{tabular}

A and group B showed significant changes on SBP, DBP, MAP, S. Creatinine, Microalbuminuria and eGFR (estimated Glomerular Filtration Rate) at 12 weeks and 24 weeks (Table 3 and Table 4).

In the Group A, diabetic patients had shown more falls in the levels of SBP as compared to DBP at 12 and 24 weeks (Table 3 and Table 4). There were increased in the mean percentage of serum creatinine and albumin in the urine (microalbuminuria), whereas, fall in value of eGFR at 12 weeks and 24 weeks, was observed (Table 3 and Table 4).

While in Group B, diabetic patients had resulted in more falls in the levels SBP as compared to DBP (Table 3 and Table 4). There were decreased in the mean percentage of serum creatinine and albumin in the urine (microalbuminuria), while, increases in the level of eGFR at 12 weeks and 24 weeks were seen.

However, insignificant $(>0.05)$ change were seen in the levels of blood urea, electrolytes (serum sodium, serum potassium and serum chloride) and liver function test (serum bilirubin, SGOT and SGPT) at the end of study in both the groups (Table 3 and Table 4).

BP goals achieved for SBP (<135 mm Hg) by $80.49 \%$ and $75.61 \%$ for DBP $(<85)$ in Group A, whereas, BP goals attained for SBP $(<135 \mathrm{~mm} \mathrm{Hg}$ ) by $89.58 \%$ and $87.50 \%$ for DBP $(<85)$ in Group B at 24 weeks.

Mild adverse events observed in Group A, were oedema feet $(1.96 \%, \mathrm{n}=1)$, and headache $(1.96 \%, \mathrm{n}=1)$ in patients, while dry cough $(3.85 \%, \mathrm{n}=2)$ and headache $(1.925 \%$, $\mathrm{n}=1$ ) were observed in Group B. None of the patients have shown serious adverse events in the study groups. However, insignificant changes were seen in LFT and RFT in the study groups during the study period.

Table 2: Baseline parameters values.

\begin{tabular}{|c|c|c|c|}
\hline Parameters & $\begin{array}{l}\text { Amlodipine } \\
(\mathrm{n}=51) \text { Value }+ \text { SD, CI }\end{array}$ & $\begin{array}{l}\text { Ramipril } \\
(\mathrm{n}=52) \text { Value } \pm \text { SD, CI }\end{array}$ & $\begin{array}{l}\text { p- } \\
\text { value* }\end{array}$ \\
\hline Age (Years) & $52.196 \pm 10.229,49.316-55.076$ & $55.57 \pm 11.551,52.358-58.796$ & $>0.05$ \\
\hline Male (\%age) & 68 & 57.69 & - \\
\hline SBP (mm Hg) & $143.725 \pm 21.40,137.70-149.75$ & $142.88 \pm 12.75,139.33-146.44$ & $>0.05$ \\
\hline $\mathrm{DBP}(\mathrm{mm} \mathrm{Hg})$ & $89.17 \pm 12.465,85.667-92.686$ & $87.88 \pm 9.501,85.237-90.532$ & $>0.05$ \\
\hline PR (Pulse rate) (beats/min) & $84.627 \pm 10.38,81.70-87.55$ & $87.038+8.887,84.562-89.515$ & $>0.05$ \\
\hline HbA1C (\%age) & $7.72 \pm 1.653,7.250-8.181$ & $7.85 \pm 1.486,7.44-8.268$ & $>0.05$ \\
\hline $\mathrm{FBS}(\mathrm{mg} / \mathrm{dl})$ & $172.76 \pm 60.356,155.77-189.76$ & $165.25 \pm 50.416,151.20-179.30$ & $>0.05$ \\
\hline Urea (mg/dl) & $25.41 \pm 6.903,23.468-27.355$ & $27.01 \pm 7.539,24.918-29.120$ & $>0.05$ \\
\hline S. Creatinine $(\mathrm{mg} / \mathrm{dl})$ & $0.79 \pm 0.228,0.7280$ to 0.8563 & $0.84 \pm 0.219,0.7764-0.8986$ & $>0.05$ \\
\hline Microalbuminuria (mg/L) & $75.65 \pm 81.83,52.613-98.689$ & $108.15 \pm 85.70,84.272-132.04$ & $>0.05$ \\
\hline eGFR (MDRD) (mL/Min/1.73m²) & $106.237 \pm 30.304,97.706-114.77$ & $97.876 \pm 27.779,90.135-105.62$ & $>0.05$ \\
\hline S. Sodium $(\mathrm{mEq} / \mathrm{L})$ & $141.76 \pm 5.086,140.33$ to 143.22 & $144.42 \pm 3.928,140.33-142.52$ & $>0.05$ \\
\hline S. Potassium (mEq/L) & $4.58 \pm 0.5403,4.43$ to 4.734 & $4.6 \pm 0.533,4.457-4.751$ & $>0.05$ \\
\hline S. Chloride (mEq/L) & $103.78 \pm 4.34,102.56$ to 105.01 & $103.5 \pm 3.263,102.61-104.43$ & $>0.05$ \\
\hline S. Bilirubin (mg/dL) & $0.6745 \pm 0.2279,0.6104$ to 0.738 & $0.633 \pm 0.2315,0.5678-0.6968$ & $>0.05$ \\
\hline SGOT (U/L) & $31.88 \pm 10.533,28.915$ to 34.846 & $33.77 \pm 20.42,28.08-39.466$ & $>0.05$ \\
\hline SGPT (U/L) & $42.029 \pm 16.995,37.245$ to 46.814 & $48.75 \pm 30.004,40.387-57.109$ & $>0.05$ \\
\hline $\mathrm{HC}(\mathrm{cm})$ & $98.73 \pm 7.59,96.587-100.86$ & $96.92 \pm 8.012,94.69-99.156$ & $>0.05$ \\
\hline $\mathrm{WC}(\mathrm{cm})$ & $99.98 \pm 10.45,97.038-102.92$ & $99 \pm 10.953,95.948-102.05$ & $>0.05$ \\
\hline BMI $\left(\mathrm{Kg} / \mathrm{m}^{2}\right)$ & $21.908 \pm 3.401,20.951-22.866$ & $21.296 \pm 3.541,20.310-22.283$ & $>0.05$ \\
\hline
\end{tabular}

*Students't test unpaired applied; CI-90\% Confidence Interval 
Table 3: Change in the parameters at 12 weeks and 24 weeks.

\begin{tabular}{|c|c|c|c|c|}
\hline \multirow{2}{*}{ Parameters } & \multicolumn{2}{|c|}{ Amlodipine Value \pm SD, CI } & \multicolumn{2}{|c|}{ Ramipril Value \pm SD, CI } \\
\hline & 12 Weeks & 24 Weeks & 12 Weeks & 24 Weeks \\
\hline SBP & $\begin{array}{l}137.70 \pm 13.552 \\
126.89-134.52\end{array}$ & $\begin{array}{l}122.94 \pm 10.48 \\
119.99-125.89\end{array}$ & $\begin{array}{l}127.15 \pm 11.91 \\
123.83-130.47\end{array}$ & $\begin{array}{l}122.27 \pm 12.52 \\
118.78-125.76\end{array}$ \\
\hline DBP & $\begin{array}{l}81.10 \pm 8.093 \\
78.820-83.376\end{array}$ & $\begin{array}{l}79.17 \pm 7.079 \\
77.184-81.169\end{array}$ & $\begin{array}{l}79.73 \pm 7.74 \\
77.57-81.88\end{array}$ & $\begin{array}{l}77.0 \pm 7.90 \\
74.79-79.203\end{array}$ \\
\hline $\begin{array}{l}\text { MAP (Mean Arterial } \\
\text { Pressure) }\end{array}$ & $\begin{array}{l}60.105 \pm 7.417 \\
58.017-62.193\end{array}$ & $\begin{array}{l}55.569+5.554 \\
54.006-57.132\end{array}$ & $\begin{array}{l}58.192+6.736 \\
56.315-60.069\end{array}$ & $\begin{array}{l}55.646 \pm 6.963 \\
53.906-57.787\end{array}$ \\
\hline PR & $\begin{array}{l}83.098 \pm 9.552 \\
80.409-85.787\end{array}$ & $\begin{array}{l}82.50 \pm 8.048 \\
80.244-84.776\end{array}$ & $\begin{array}{l}85.23 \pm 8.30 \\
82.918-87.54\end{array}$ & $\begin{array}{l}84.769 \pm 9.2 \\
82.20-87.334\end{array}$ \\
\hline B. Urea & $\begin{array}{l}26.41 \pm 6.792 \\
23.468-27.355\end{array}$ & $\begin{array}{l}25 \pm 5.84 \\
23.92-27.213\end{array}$ & $\begin{array}{l}26.53 \pm 7.586 \\
24.425-28.652\end{array}$ & $\begin{array}{l}25.44+5.952 \\
23.784-27.101\end{array}$ \\
\hline S. Creatinine & $\begin{array}{l}0.84 \pm 0.267 \\
0.7639-0.9146\end{array}$ & $\begin{array}{l}0.98 \pm 0.3122 \\
0.8239-0.9997\end{array}$ & $\begin{array}{l}0.81 \pm 0.1636 \\
0.7640-0.8552\end{array}$ & $\begin{array}{l}0.79 \pm 0.2204 \\
0.7353-0.8493\end{array}$ \\
\hline Micro-albuminuria & $\begin{array}{l}96.55 \pm 91.10 \\
70.901-122.20\end{array}$ & $\begin{array}{l}120.94 \pm 101.53 \\
92.358-149.52\end{array}$ & $\begin{array}{l}93.80 \pm 77.28 \\
72.27-115.34\end{array}$ & $\begin{array}{l}81.40 \pm 74.96 \\
60.515-102.29\end{array}$ \\
\hline $\begin{array}{l}\text { eGFR } \\
\text { (MDRD) }\end{array}$ & $\begin{array}{l}102 \pm 29.40 \\
94.169-110.72\end{array}$ & $\begin{array}{l}95.25 \pm 32.057 \\
86.229-104.28\end{array}$ & $\begin{array}{l}98.336 \pm 25.22 \\
91.309-105.37\end{array}$ & $\begin{array}{l}107.72+31.00 \\
99.087-116.37\end{array}$ \\
\hline S. Sodium & $\begin{array}{l}141.18 \pm 3.205 \\
140.18-141.98\end{array}$ & $\begin{array}{l}140.78 \pm 4.780 \\
139.44-142.13\end{array}$ & $\begin{array}{l}141.98 \pm 3.843 \\
140.91-143.05\end{array}$ & $\begin{array}{l}141.30 \pm 4.151 \\
140.02-142.6\end{array}$ \\
\hline S. Potassium & $\begin{array}{l}4.46 \pm 0.453 \\
4.337-4.592\end{array}$ & $\begin{array}{l}4.465 \pm 0.436 \\
4.342-4.588\end{array}$ & $\begin{array}{l}4.66 \pm 0.3813 \\
4.561-4.774\end{array}$ & $\begin{array}{l}4.76 \pm 0.4453 \\
4.643-4.891\end{array}$ \\
\hline S. Chloride & $\begin{array}{l}103.47 \pm 3.39 \\
102.51-104.43\end{array}$ & $\begin{array}{l}103.37 \pm 4.47 \\
102.11-104.63\end{array}$ & $\begin{array}{l}103.69 \pm 2.873 \\
102.89-104.49\end{array}$ & $\begin{array}{l}103.50 \pm 3.410 \\
102.55-104.45\end{array}$ \\
\hline S. Bilirubin & $\begin{array}{l}0.656 \pm 0.148 \\
0.6150-0.6987\end{array}$ & $\begin{array}{l}0.598 \pm 0.1516 \\
0.555-0.6407\end{array}$ & $\begin{array}{l}0.6057 \pm 0.1685 \\
0.5588-0.6527\end{array}$ & $\begin{array}{l}0.5596 \pm 0.162 \\
0.5144-0.6049\end{array}$ \\
\hline SGOT & $\begin{array}{l}33.57 \pm 10.678 \\
30.563-36.575\end{array}$ & $\begin{array}{l}32.10 \pm 10.631 \\
29.105-35.091\end{array}$ & $\begin{array}{l}29.94 \pm 12.266 \\
26.52-33.36\end{array}$ & $\begin{array}{l}28.57 \pm 10.02 \\
25.78-31.36\end{array}$ \\
\hline SGPT & $\begin{array}{l}42.47 \pm 18.846 \\
77.165-47.776\end{array}$ & $\begin{array}{l}38.9 \pm 13.42 \\
35.124-42.680\end{array}$ & $\begin{array}{l}44.08 \pm 21.45 \\
38.10-50.054\end{array}$ & $\begin{array}{l}39.65 \pm 39.654 \\
34.375-44.375\end{array}$ \\
\hline
\end{tabular}

CI-90\% Confidence Interval

Table 4: Statistical value of the parameters at 12 weeks and 24 weeks.

\begin{tabular}{|c|c|c|c|c|c|c|c|c|}
\hline \multirow[b]{2}{*}{ Parameters } & \multicolumn{4}{|c|}{ Amlodipine } & \multicolumn{4}{|l|}{ Ramipril } \\
\hline & $\begin{array}{l}0-12 \\
\text { weeks }\left(\mathrm{p}^{*}\right)\end{array}$ & $\begin{array}{l}\text { 12-24 } \\
\text { weeks }\left(p^{*}\right)\end{array}$ & $\begin{array}{l}\text { 0-24 } \\
\text { Weeks(p*) }\end{array}$ & p ** & $\begin{array}{l}0-12 \\
\text { Weeks }\left(p^{*}\right)\end{array}$ & $\begin{array}{l}\text { 12-24 } \\
\text { weeks(p*) }\end{array}$ & $\begin{array}{l}0-24 \\
\text { weeks }\left(\mathrm{p}^{*}\right)\end{array}$ & $\mathbf{p}^{* *}$ \\
\hline SBP & $<0.0001$ & $<0.0001$ & $<0.0001$ & $<0.0001$ & $<0.0001$ & $<0.001$ & $<0.0001$ & $<0.0001$ \\
\hline DBP & $<0.0001$ & $<0.0003$ & $<0.0001$ & $<0.0001$ & $<0.001$ & $<0.003$ & $<0.0001$ & $<0.0001$ \\
\hline MAP & $<0.0001$ & $<0.0001$ & $<0.0001$ & $<0.0001$ & $<0.0001$ & $<0.0001$ & $<0.0001$ & $<0.0001$ \\
\hline PR & $>0.05$ & $>0.05$ & $<0.01$ & $>0.05$ & $<0.001$ & $>0.05$ & $<0.01$ & 0.01 \\
\hline B. Urea & $>0.05$ & $>0.05$ & $>0.05$ & $>0.05$ & $>0.05$ & $>0.05$ & $>0.05$ & $>0.05$ \\
\hline S. Creatinine & $>0.05$ & $<0.001$ & $<0.001$ & $<0.001$ & $>0.05$ & $>0.05$ & $>0.05$ & $>0.05$ \\
\hline Micro-albuminuria & $<0.001$ & $<0.0001$ & $<0.0001$ & $<0.05$ & $<0.001$ & $<0.001$ & $<0.0001$ & $<0.05$ \\
\hline eGFR MDRM & $>0.05$ & $<0.01$ & $<0.01$ & $<0.01$ & $>0.05$ & $<0.03$ & $<0.02$ & $<0.01$ \\
\hline S. Sodium & $>0.05$ & $>0.05$ & $>0.05$ & $>0.05$ & $>0.05$ & $>0.05$ & $>0.05$ & $>0.05$ \\
\hline S. Potassium & $<0.01$ & $>0.05$ & $>0.05$ & $>0.05$ & $>0.05$ & $>0.05$ & $>0.05$ & $>0.05$ \\
\hline Chloride & $>0.05$ & $>0.05$ & $>0.05$ & $>0.05$ & $>0.05$ & $>0.05$ & $>0.05$ & $>0.05$ \\
\hline S. Bilirubin & $>0.05$ & $<0.01$ & $<0.01$ & $>0.05$ & $>0.05$ & $>0.05$ & $>0.05$ & $>0.05$ \\
\hline SGOT & $>0.05$ & $>0.05$ & $>0.05$ & $>0.05$ & $>0.05$ & $>0.05$ & $>0.05$ & $>0.05$ \\
\hline SGPT & $>0.05$ & $<0.05$ & $>0.05$ & $>0.05$ & $>0.05$ & $<0.05$ & $<0.05$ & $>0.05$ \\
\hline
\end{tabular}

*Students't test (paired test); **Post-hoc ANOVA 
Table 5: Comparison between the study groups.

\begin{tabular}{|c|c|c|c|}
\hline \multirow{2}{*}{$\begin{array}{l}\text { Para- } \\
\text { meters }\end{array}$} & \multirow{2}{*}{$\begin{array}{l}\text { Students't test } \\
\text { (Un-paired) }\end{array}$} & \multicolumn{2}{|c|}{ Amlodipine vs Ramipril } \\
\hline & & 12 weeks & 24 weeks \\
\hline \multirow[t]{2}{*}{ SBP } & $\mathrm{p}$ & $>0.05$ & $>0.05$ \\
\hline & $\mathrm{CI}$ & $\begin{array}{l}-8.536 \text { to } \\
1.432\end{array}$ & $\begin{array}{l}-5.192 \text { to } \\
3.848\end{array}$ \\
\hline \multirow[t]{2}{*}{ DBP } & $\mathrm{p}$ & $>0.05$ & $>0.05$ \\
\hline & $\mathrm{CI}$ & $\begin{array}{l}-4.462 \text { to } \\
1.728\end{array}$ & $\begin{array}{l}-5.112 \text { to } \\
0.7587\end{array}$ \\
\hline \multirow[t]{2}{*}{ MAP } & $\mathrm{p}$ & $>0.05$ & $>0.05$ \\
\hline & $\mathrm{CI}$ & $\begin{array}{l}-4.681 \text { to } \\
0.8556\end{array}$ & $\begin{array}{l}-2.187 \text { to } \\
2.742\end{array}$ \\
\hline \multirow[t]{2}{*}{ PR } & $\mathrm{p}$ & $>0.05$ & $>0.05$ \\
\hline & CI & $\begin{array}{l}-1.363 \text { to } \\
5.628\end{array}$ & $\begin{array}{l}-1.123 \text { to } \\
5.642\end{array}$ \\
\hline \multirow[t]{2}{*}{ B. urea } & $\mathrm{p}$ & $>0.05$ & $>0.05$ \\
\hline & CI & $\begin{array}{l}-2.690 \text { to } \\
2.943\end{array}$ & $\begin{array}{l}-2.432 \text { to } \\
2.179\end{array}$ \\
\hline \multirow[t]{2}{*}{ S. creatinine } & $\mathrm{p}$ & $>0.05$ & $<0.02$ \\
\hline & $\mathrm{CI}$ & $\begin{array}{l}-0.1161 \text { to } \\
0.05692\end{array}$ & $\begin{array}{l}-0.224 \text { to }- \\
0.01646\end{array}$ \\
\hline \multirow[t]{2}{*}{ Micro-albuminuria } & $\mathrm{p}$ & $>0.05$ & $<0.05$ \\
\hline & $\mathrm{CI}$ & $\begin{array}{l}-35.739 \text { to } \\
30.256\end{array}$ & $\begin{array}{l}-74.374 \text { to }- \\
4.701\end{array}$ \\
\hline \multirow[t]{2}{*}{ eGFR (MDRM) } & $\mathrm{p}$ & $>0.05$ & $<0.05$ \\
\hline & $\mathrm{CI}$ & $\begin{array}{l}-14.518 \text { to } \\
6.591\end{array}$ & $\begin{array}{l}0.1459 \text { to } \\
24.799\end{array}$ \\
\hline \multirow[t]{2}{*}{ S. sodium } & $\mathrm{p}$ & $>0.05$ & $>0.05$ \\
\hline & $\mathrm{CI}$ & $\begin{array}{l}-0.4843 \text { to } \\
2.289\end{array}$ & $\begin{array}{l}-1.316 \text { to } \\
2.363\end{array}$ \\
\hline \multirow[t]{2}{*}{ S. potassium } & $\mathrm{p}$ & $<0.01$ & $<0.001$ \\
\hline & $\mathrm{CI}$ & $\begin{array}{l}-0.3662 \text { to } \\
0.03899\end{array}$ & $\begin{array}{l}-0.4750 \text { to } \\
0.1302\end{array}$ \\
\hline \multirow[t]{2}{*}{ S. chloride } & $\mathrm{p}$ & $>0.05$ & $>0.05$ \\
\hline & CI & $\begin{array}{l}-1.007 \text { to } \\
1.450\end{array}$ & $\begin{array}{l}-1.425 \text { to } \\
1.680\end{array}$ \\
\hline \multirow[t]{2}{*}{ S. bilirubin } & $\mathrm{p}$ & $>0.05$ & $>0.05$ \\
\hline & $\mathrm{CI}$ & $\begin{array}{l}-0.119 \text { to } \\
0.0091\end{array}$ & $\begin{array}{l}-0.1025 \text { to } \\
0.02185\end{array}$ \\
\hline \multirow[t]{2}{*}{ SGOT } & $\mathrm{p}$ & $>0.05$ & $>0.05$ \\
\hline & $\mathrm{CI}$ & $\begin{array}{l}-8.125 \text { to } \\
0.8722\end{array}$ & $\begin{array}{l}-7.558 \text { to } \\
0.5161\end{array}$ \\
\hline \multirow[t]{2}{*}{ SGPT } & $\mathrm{p}$ & $>0.05$ & $>0.05$ \\
\hline & $\mathrm{CI}$ & $\begin{array}{l}-6.292 \text { to } \\
9.505\end{array}$ & $\begin{array}{l}-5.516 \text { to } \\
7.020\end{array}$ \\
\hline
\end{tabular}

CI-90\% Confidence Interval

\section{DISCUSSION}

Diabetic nephropathy is one of the serious complications in patients of T2DM, therefore, it become necessary to prevent or treat it at an early stage, so that ESRD could be prevented. ${ }^{7}$ Studies have shown that strict control of blood glucose with antidiabetic agents is inadequate to prevent the diabetic nephropathy; therefore, it is also important to treat the other co-morbid conditions concurrently while keeping in mind the blood pressure and markers/predictors of renal disease (serum creatinine, albumin in urine and eGFR). ${ }^{7}$ It has been seen that antihypertensive agents not only control the blood pressure but also reduces the CVDs events and renal complication. ${ }^{5,7}$ Hence, it becomes important to evaluate the exact role of these antihypertensive agents and on the markers of renal disease. So, that, we could use these agents in a better way. In this study we have assess the role of Amlodipine and Ramipril on the blood pressures, markers of renal disease and other parameters.

\section{Group A}

Amlodipine (2.5-10 mg per day) resulted in statistically significant fall in levels of SBP and DBP at 12 weeks and 24 weeks (Table 3 and Table 4). Falls in SBP (-6.02 $\mathrm{mmHg}, 4.19 \%$ at 12 weeks) is less while falls in DBP ($8.07 \mathrm{mmHg}, 9.05 \%$ ) is more as reported by Pahor M, et al $(10 \mathrm{mmHg}$ and $5 \mathrm{~mm}$ of $\mathrm{Hg}$ respectively, at 8 weeks in patients of T2DM with hypertension). ${ }^{12}$ While, at 24 weeks both SBP and DBP fall is more in this study as compared to Zaman ZA, et al (14 $\mathrm{mm} \mathrm{Hg}(8.43 \%)$ and 8 $\mathrm{mm} \mathrm{Hg}(8.16 \%)$ in patients of hypertension with or without T2DM at 24 weeks). ${ }^{13}$

In comparison to Agodoa LY, et al both SBP and DBP fall is less at 12 weeks $(6.02 \mathrm{mmHg}$ and $8.07 \mathrm{mmHg}$ ) while more fall is seen in both these BP at 24 weeks (20.76 $\mathrm{mmHg}$ and $10 \mathrm{mmHg}$ respectively at 12 and 24 weeks) in this study. ${ }^{14}$ Mean arterial pressure (MAP) also decreased significantly at 12 and 24 weeks $(9.06 \%$ and $15.92 \%, \mathrm{p}<0.001$, both). While decreased in pulse rate is (by $2.51 \%, \mathrm{p}>0.05$ ) an agreement with the Kojima $\mathrm{S}$, et al $(+2.99 \%, \mathrm{p}>0.05)$ at 24 weeks. $^{15}$

Table 6: Goal achieved according to JNC VII guidelines.

\begin{tabular}{|llllll|}
\hline & \multicolumn{2}{l}{ Amlodipine $(\mathbf{n}=\mathbf{4 1})$} & \multicolumn{2}{l|}{ Ramipril $(\mathbf{n}=\mathbf{4 8})$} & p-value* at 12 and 24 weeks \\
Parameters & 12 weeks & 24weeks & 12weeks & 24weeks & \\
\hline SBP <135 (\%age) & $26(63.41)$ & $33(80.49)$ & $36(75)$ & $43(89.58)$ & $>0.05$, both \\
\hline DBP <85 (\%age) & $26(63.41)$ & $31(75.61)$ & $37(77.08)$ & $42(87.50)$ & $>0.05$, both \\
\hline
\end{tabular}

*Fischer's exact test at 12 and 24 weeks 
Increased serum creatinine level is (by $4.93 \%$ and $24.05 \%$ at 12 weeks and 24 weeks) much more as revealed by Zaman ZA, et al $(+2.7 \%)$ and Kojima $S$ et al $(+2.7 \%){ }^{13-15}$

Blood urea is (increased by $3.93 \%$ and $1.61 \%, \mathrm{p}>0.05$, both at 12 and 24 weeks) while contrast result is noticed by other study $(-1.58 \%, \mathrm{p}>0.05) .{ }^{15}$ Increase in urinary albumin (by $59.87 \%$ ) at 24 weeks, is more or less as reported by Agodoa LY et al (58\% for urinary protein) 14 but more than as disclosed by KOJIMA S et al $(30.12 \%)$ and Zaman ZA et al $(16.67 \%$, urinary protein/creatinine ratio) (both studies was conducted on patients of hypertension with or without T2DM). ${ }^{13-15}$

Fall in value of eGFR at 12 weeks and 24 weeks was observed.

Amlodipine group achieved BP goals for SBP (<135 mm $\mathrm{Hg})$ by $80.49 \%$ and $75.61 \%$ for DBP $(<85)$ at end of study (Table 6).

\section{Group B}

Ramipril (2.5-10 mg per day) in group B resulted in statistically significant fall in levels of SBP and DBP, respectively at 12 weeks and 24 weeks (Table 3 and Table 4). With Ramipril, a mean fall of 15.17 (11.01\%) $\mathrm{mmHg}$ in SBP and $8.15(9.27 \%) \mathrm{mmHg}$ in DBP (at 12 weeks) are seen which are more fall as reported by Pahor $\mathrm{M}$, et al $(-8 \mathrm{mmHg}$ in SBP and $-3 \mathrm{mmHg}$ in DBP with fosinopril $20-40 \mathrm{mg}$ per day at 4 weeks). ${ }^{12}$

Whereas, fall of SBP in our study is less as revealed by Soni U, et al $(41.47 \mathrm{mmHg}, 25.4 \%)$ at 12 weeks. ${ }^{16}$ However, this fall of SBP at 12 weeks is slightly less while more at 24 weeks (Table 2) as compared to another study (Agodoa LY, et al) $(17 \mathrm{mmHg}, 11.21 \%$ and 16.5 $\mathrm{mmHg}, 10.93 \%$ respectively, $\mathrm{p}<0.05$, both). ${ }^{14}$

While fall of DBP $(8.15 \mathrm{mmHg}, 9.27 \%$ and $12.38 \mathrm{mmHg}$, $10.88 \%)$ are less as compared to Agodoa LY, et al (13.6 $\mathrm{mmHg}, 11.87 \%$ and $14.8 \mathrm{mmHg}, 14.8 \%$, respectively at 12 weeks and 24 weeks) and Soni U, et al (16.67 $\mathrm{mmHg}$, $16.89 \%$, at 12 weeks) but more as revealed by Andersen $\mathrm{K}$, et al (10.2 $\mathrm{mmHg}, 10.88 \%$, at 12 weeks). ${ }^{14,16,17}$

Mean arterial pressure (MAP) is reduced by $11.78 \%$ and $15.33 \%$ ( $\mathrm{p}<0.001$, both), respectively at 12 and 24 weeks.

Decrease in the level of serum creatinine (-0.02 and -0.05 at 12 and 24 weeks) is more or less as reported by Barnett $\mathrm{AH}$, et al $(-0.1){ }^{18}$

While decreased in urinary albumin level $(-26.75 \%$, $\mathrm{p}<0.001,24$ weeks) is more as disclosed by Agodoa LY, et al $(-20 \%, \mathrm{p}<0.01$ for urinary protein at 24 weeks $) .{ }^{14}$

Increased in eGFR $\left(+10.06 \mathrm{ml}\right.$ per minute per $1.73 \mathrm{~m}^{2}$ BSA, $+10.29 \%$ at 24 weeks) (Table 3 and Table 4 ) is seen in our study while contrast result was disclosed by Barnett AH, et al (-14.9 ml per minute per $1.73 \mathrm{~m}^{2} \mathrm{BSA}$ after therapy with enalapril $20 \mathrm{mg}$ per day in patients of T2DM with late stage nephropathy cases at 60 weeks). ${ }^{18}$ This improvement in eGFR value of our study is contrast to previous study may be because of ACE inhibitor is prescribed in patients are who have not developed late stage of Diabetic nephropathy (stage of proteinuria), whereas we conducted this study in patients who are at early stage of diabetic nephropathy (microalbuminuria or macroalbuminuria). ${ }^{18}$ This shows that ramipril therapy leads to improvement in the eGFR along with decline in albumin level in the urine, which indirectly provide evidence that it hindered the process of nephropathy in T2DM patients. This renoprotective effects of Ramipril (i.e. ACE inhibitor) is due to their pleiotropic actions viz. ACE inhibition, antiproliferative action as well as lowering of blood pressure and maintaining of intraglomerular pressure in the kidney.

SBP goals achieved $(75 \%, \mathrm{p}<0.05)$ is more as reported by Anderson $\mathrm{K}$ et al. $(25.3 \%, \mathrm{p}<0.05$ in hypertensive patients) at the end of 12 weeks. ${ }^{17}$ At 24 weeks, SBP goals $(<135 \mathrm{~mm} \mathrm{Hg})$ is achieved by $89.58 \%$ while for DBP is $87.50 \%(<85 \mathrm{mmHg})$ in our study (Table 6).

Ramipril in Group-B, leads to dry cough $(3.85 \%, \mathrm{n}=2)$ and headache $(1.92 \%, \mathrm{n}=1)$ that are less as reported by Soni U, et al $(13.33 \%$ and $3.33 \%)$ and Andersen K, et al $(6.9 \%$ and $6.9 \%) .^{16,17}$

\section{Comparison between Group A and Group B}

On comparing Amlodipine therapy (Group A) versus Ramipril therapy (Group B), it was found that both the therapies are equally effective in improving the SBP, DBP and MAP at 12 and 24 weeks (Table 3 and Table 4). Whereas, both the therapies had not shown statistically significant difference on the blood urea, s. sodium, s. potassium, s. chloride, s. bilirubin, SGOT and SGPT levels at 12 weeks and 24 weeks, respectively. However, there is increase in mean percentage of serum creatinine and albuminuria while decline in eGFR in the Amlodipine treated group as compared to Ramipril treated Group which show contrast result. Consequently, Ramipril improve the levels of markers of renal function (s. creatinine, albuminuria and eGFR) while decline in these parameters is observed in the Amlodipine treated group.

Both the therapies lead to mild side effects which were seen like oedema feet and headache in Amlodipine Group, whereas, dry cough is observed with Ramipril Group. Clinical examination and blood investigations of the patients have not shown any serious adverse events during the study period, thus indicated that both the therapies were well tolerated by the patients and also none of the patients left or withdrawn during the study period. 


\section{Implications of the study}

Hence, the findings of this study about Ramipril effects on the improvement of markers of renal disease parameters (serum creatinine, albumin in the urine and eGFR) and better Blood Pressure goals achievement, suggested that it has renoprotective property in addition to its antihypertensive action, better efficacy and lesser side effects as compared to Amlodipine. Therefore, Ramipril can be helpful to prevent and manage the cases of diabetic nephropathy at an early stage and useful to prevent serious life threatening complications if it is prescribed appropriately in T2DM patients.

\section{Limitations}

Our study had a few limitations. The diabetes patients with serious comorbid condition (CHF, AMI, stroke, $\mathrm{CKD}$, etc.) admitted in the hospital were not included in the study. The diabetic patients who underwent surgery recently and paediatric diabetic patients and pregnancy induced diabetes patients and type $1 \mathrm{DM}$ were also excluded. Moreover, our study was done for a short period of time and the number of patients studied was low. Hence, A double blind RCT with large sample size and longer duration is needed for the better analysis of the under study drugs.

\section{CONCLUSION}

Both the drugs efficiently improved the SBP, DBP and MAP as well as achieved the Blood pressure goals for T2DM with hypertension patients. But ramipril also improves the markers of renal disease (viz. serum creatinine, albuminuria and eGFR); therefore it also has renoprotective propriety along with antihypertensive action. As a result, ramipril as being ACE inhibitor has pleiotropic effects and can be used rationally as well as prophylactically to prevent the decline in the renal function in patients of T2DM cases.

\section{ACKNOWLEDGEMENT}

Expert statistical support was provided by Dr. Beltej Singh, Ph.D, Lecturer in statistics, Deptt. Of SPM, GGS Medical College, Faridkot.

Funding: No funding sources Conflict of interest: None declared

Ethical approval: The study was approved by the Institutional Ethics Committee

\section{REFERENCES}

1. Kasper DL, Fauci AS, Longo DL, Braunwald E, Hauser SL, Jameson JL. Powers AC. Diabetes Mellitus. In. Harrison's Princples of Internal Medicine. 17th edition. New York: McGraw-Hill Medical Publishing division. 2008:2275-2304.
2. World Health Organization. Development and Updation of the diabetes Mellitus ATLAS of India. Available at: http:www.whoindia.org/Link Files/ NMH_Resources_Diabetes_atlas.pdf. Accessed on 1 April 2011.

3. Wild S, Roglic G, Green A, Sicree R, King J. Global prevalence of diabetes-Estimates for the year 2000 and projections for 2030, Diabetes Care. 2004;27:1047-53.

4. International Diabetes Federation. IDF Diabetes Atlas Sixth edition. Available at https://www.idf.org/sites/default/files/EN_6E_Atlas _Full_0.pdf. Assessed on 17 Oct. 2015.

5. Blood Pressure Lowering Treatment Trialists' Collaboration. Blood pressure lowering and major cardiovascular events in people with and without chronic kidney disease: meta-analysis of randomised controlled trials. BMJ. 2013;347:f5680. Available at:

http://www.bmj.com/content/bmj/347/bmj.f5680.ful. pdf. Accessed on 17 Oct 2015 at 06:38 AM.

6. International Diabetes Federation. Metabolic syndrome-driving the CVD epidemic. Available at https://www.idf.org/webdata/docs/Diabetes_meta_sy ndrome.pdf. Accessed on 17 Oct 2015 at 08:10 AM.

7. Chadban S, Howell M, Twigg S, Thomas M, Jerums G, Cass A. Prevention and management of chronic kidney disease in type 2 diabetes. Nephrology. 2010;15:S162-94.

8. Benowitz NL. Antihypertensive Agents. In: Katzung BG, Masters SB, Trevor AJ, editors. Basic and Clinical Pharmacology. 11th edition. New Delhi: Tata McGraw-Hill Education Private Limited. 2009:167-189.

9. Weber MA, Schiffrin EL, White WB, Mann S, Lindholm LH, Kenerson JG. Clinical Practice Guidelines for the Management of Hypertension in the Community A Statement by the American Society of Hypertension and the International Society of Hypertension. The Journal of Clinical Hypertension. 2014;16(1):14-26. Available at http://csc.cma.org.cn/attachment/2014315/13948854 45745.pdf. Assessed on 17 Oct 2015.

10. Kumar R, Kohli K, Kajal HL. A study of drug prescribing pattern and cost analysis among diabetic patients in a tertiary care teaching institute in north India. Journal of Drug Delivery \& Therapeutics; 2013;3(2):56-61. Available at http://jddtonline.info/index.php/jddt/article/view/431 /246. Assessed on 17 Oct 2015.

11. Gitanjali, Goyal S, Panag KMDS. Role of urinary albumin to creatinine ratio and spot albuminuria in predicting significant albuminuria in patients of diabetic nephropathy. Journal of Evolution of Medical and Dental Sciences; 2014;3(1):38-45.

12. Pahor M, Franse LV, Deitcher SR, Cushman WC, Johnson KC, Shorr RI. Fosinopril Versus Amlodipine Comparative Treatments Study- A Randomized Trial to Assess Effects on Plasminogen Activator Inhibitor-1. Circulation. 2002;105:457-61. 
13. Zaman ZA, Kumari V. Comparison of the effects of amlodipine and cilnidipine on blood pressure, heart rate, proteinuria and lipid profile in hypertensive patients. Int J Basic Clin Pharmacol. 2013;2:160-4.

14. Agodoa LY, Appel L, Bakris GL, Beck G, Bourgoignie J, Briggs JP. Effect of ramipril vs amlodipine on renal outcomes in hypertensive nephrosclerosis. JAMA. 2001;285(21):2719-28.

15. Kojima S, Shida M, Yokoyama H. Comparison between Cilnidipine and Amlodipine Besilate with Respect to Proteinuria in Hypertensive Patients with Renal Diseases. Hypertens Res. 2004;27(6):379-85.

16. Soni U, Moghe VV, Jain P, Upadhyaya P. A Comparative Study of Efficacy and Tolerability of Telmisertan and Ramipril. International Journal of Pharma Sciences. 2013;3(3):240-43.

17. Andersen K, Weinberger $\mathrm{MH}$, Egan B, Constance CM, Wright M, Lukashevich. Comparative Efficacy of Aliskiren Monotherapy and Ramipril Monotherapy in Patients with stage 2 Systolic Hypertension: Subgroup Analysis of a Double-blind, Active Comparator Trial. Cardiovascular Therapeutics. 2010;28:344-49.

18. Barnett AH, Bain SC, Bouter P, Karlberg B, Madsbad S, Jervell J, et al. Angiotensin-Receptor Blockade versus Converting-enzyme Inhibition in Type 2 Diabetes and Nephropathy. N Engl J Med. 2004;4:351(19):1952-61.

Cite this article as: Kumar R, Panag KMDS, Paul K, Kohli K, Kazal HL. Comparative study of amlodipine versus ramipril and their effects on markers of renal disease in type 2 diabetes mellitus. Int J Basic Clin Pharmacol 2016;5:458-65. 